\begin{tabular}{|c|c|}
\hline 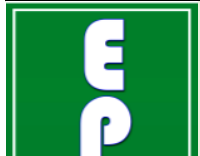 & $\begin{array}{c}\text { International Journal of Current Research } \\
\text { and Academic Review }\end{array}$ \\
\hline $\begin{array}{l}\text { EXCELLENT } \\
\text { PUBLLSHERS }\end{array}$ & $\begin{array}{c}\text { ISSN: 2347-3215 (Online) Volume } 7 \text { Number } 4 \text { (April-2019) } \\
\text { Journal homepage: } \text { http://www.ijcrar.com }\end{array}$ \\
\hline
\end{tabular}

doi: https://doi.org/10.20546/ijcrar.2019.704.010

\title{
Genetic Distance and Variation among Cotton (Gossypium hirsutum. L) Genotypes for Yield Traits in Kamashi District of Benishangul-Gumuz Regional State, Ethiopia
}

\author{
Kedir Wulchafo Hussen* \\ Ethiopian Institute of Agricultural Research, Assosa Agricultural Research Center, Assosa, Ethiopia \\ *Corresponding author
}

\section{Abstract}

The present research was carried out to determine and record genetic distance and variation among cotton (Gossypium hirsutum L) genotypes for yield traits in Kamashi district of benishangul-gumuz regional state for fourteen upland cotton genotypes. The genotypes were evaluated for ten traits in randomized complete block design with three replications. Data were collected on days of $50 \%$ flowering, days to $65 \%$ boll opening, plant height, Number of monopodial branches per plant, Number of sympodial branches per plant, Boll number per plant, Boll weight Seed cotton yield per hectare, Lint yield and Ginning out tern. The data were subjected to analysis of variance. Genotypes were varied significantly for most of the traits studied and there were wide range variation on mean values for most of the traits which indicated the presence of variability among the tested genotypes.
\end{abstract}

\section{Article Info}

Accepted: 04 March 2019

Available Online: 20 April 2019

\section{Keywords}

Mean performance, Heritability, Genetic advance, upland cotton, Variability

\section{Introduction}

Cotton (Gossypium spp.) is an economically important crop around the world, providing the most natural fiber for the manufacture of textiles. Gossypium contains more than 50 recognized species belonging to eight genome groups (Wendel and Grover, 2015). Only four species, G. herbaceeum (A1), G. arboreum (A2), G. hirsutum (AD1), and $G$. barbadense (AD2) have been domesticated and cultivated widely. G. hirsutum L. $(2 n=4 x=52, \quad$ genome $\quad$ size: $2.5 \mathrm{~Gb}$; Li et al., 2014a, 2015; Wendel and Grover, 2015), also called upland cotton, is cultivated worldwide and accounts for more than $95 \%$ of cotton production (Chen et al., 2007; Zhang et al., 2008).
The worldwide economic impact of the cotton industry is estimated at $\sim \$ 500$ billion/year with an annual utilization of $\sim 115$ million bales or $\sim 27$ million metric tons of cotton fiber (Chen et al., 2007). The top cotton producer in the world is China, U.S.A, India, Middle East, Australia and Pakistan (Spectrum Commodities, 2012). These countries are rich in climatic conditions for growth of the crop. Similarly, in terms of cotton production, the five most popular producers of European countries are Italy, Germany, France, Spain, and UK where they account nearly for three quarters of the E.U production of the textiles, and clothes (European Commission, 2011).

Estimation of the magnitude of variation within genotype for important plant attributes will enable breeders to exploit genetic diversity more efficiently. In breeding 
programs, selection is an integral part by which genotypes with high productivity in a given environment could be developed. Indirect selection through related yield components will be more fruitful. Morphological traits are commonly used to evaluate genetic variation since their measurements are simple (Tsedeke, 2007).

Cotton is a crop of manifold merits in the world. Simultaneously it is used as a fiber, food and a feed; its lint is used for making cloth. Low quality lint is used as a raw material in the manufacture of high-grade writing paper and rayon, and in the chemical industry for making photographic and X-ray films (Berger, 1969). The oil is one of the most valuable products for cotton next to soybean. The refined oil is used in cooking and the oil cake residue as a protein feed for ruminant livestock (Lee, 2009). The edible-grade cotton seed flour can be used as human food in at least three ways: as a protein supplement in cereal grains and in vegetable protein mixtures; as an additive in bakery products, and as filler in meat-like products (Anonymous, 2008). In Africa, Asia and Latin America, cotton is contributing a lot towards overcoming food insecurity. In Africa, thirtyfive of the fifty-five countries produce cotton. Twentytwo of these countries are known for exporting cotton (Valderrama, undated, 2007 online).

Production of cotton in Ethiopia has been increasing in the last few years in general and in Benisangul-Gumuze Regional State in particular, but productivity of cotton is generally low. SOFERCO (2016) reported that current world's productivity average of cotton lint is about 760 $\mathrm{kg} / \mathrm{ha}$ ( 2.054 tons/ha), and As the report, current cotton productivity of Ethiopia is estimated to 2.0-3.0 tons/ha (under irrigation) and 1.2-1.7 tons/ha (under rain-fed).

Many factors including biotic (disease, insects, and weeds), and abiotic factors (drought, low soil fertility, salinity, etc.); also, not using appropriate technologies (improved variety and fertilizer) do contribute to the low productivity. Therefore, developing improved varieties is one of the measures to alleviate these constraints. In this regard, studying is the primary precondition that breeders look into for the development of new varieties. So far no studies on genetic distance and variation of different cotton traits contributing to yield parameters have been carried out in Kamashi district of Beneshangul-Gumuz Regional State, Ethiopia. In view of these gaps, the present investigations were carried out to determine and record genetic distance and variation among cotton (Gossypium hirsutum. L) genotypes for yield traits in kamashi district of benishangul-gumuz regional state.

\section{Materials and Methods}

\section{Description of the Study Area}

The field experiments were conducted at Kamashi subtesting site of Assosa agricultural research center to determine and record genetic distance and variation among cotton (Gossypium hirsutum. L) genotypes for yield traits. For this purpose, fourteen upland cotton genotypes were studied (Table 1). The experiment was conducted in randomized complete block design with three replications. Five rows of $5 \mathrm{~m}$ length were used for each plot. Inter-row and intra-row spacing of $90 \mathrm{~cm}$ and $20 \mathrm{~cm}$, respectively, were used to make up plot sizes of $22.5 \mathrm{~m}^{2}$ (5 rows $\times 5 \mathrm{~m} \times 0.9 \mathrm{~m}$ ) each. This translates to a population of about 55,000 plants on a per hectare basis.

\section{Data Collection}

For agronomic and yield parameters, data were recorded for the following traits; Days to 50\% flowering, Days to $65 \%$ boll opening, Plant height (PHt), Number of monopodial, sympodial branches per plant, Number of bolls per plant. The average Boll weight (g), Seed Cotton yield per plant (gm), Lint Percentage (GOT) and Lint yield

\section{Data Analysis}

\section{Analysis of variance}

The data collected were subjected to statistical analysis. First, the analysis was done using the SAS computer program, version 9.0 (SAS, 2002). Mean separation was conducted Dunkan's multiple range test (DMRT) at 0.05 probability level

Analysis of variance in a randomized complete block design was computed using the following model:

$Y i j=\mu+r j+g i+\varepsilon i j$

Where,

Yij = the response of trait $\mathrm{Y}$ in the $i$ th genotype and the $j$ th replication

$\mu=$ the grand mean of trait $Y$;

$\mathrm{rj}=$ the effect of the $j$ th replication;

$\mathrm{gi}=$ the effect of the $i$ th genotype; and

$\varepsilon \mathrm{ij}=$ experimental error effect. 


\section{Phenotypic and genotypic variances}

The phenotypic and genotypic variances of each trait were estimated from the RCBD analysis of variance and the expected mean squares under the assumption of random effects model computed from linear combinations of the mean squares and the phenotypic and genotypic coefficient of variations, which were also computed as per the methods suggested by Burton et al., (1953).

Genotypic variance $\left(\sigma^{2} \mathrm{~g}\right)=\frac{\text { Msg }- \text { Mse }}{\mathrm{r}}$

Environmental variance $\left(\sigma^{2} \mathrm{e}\right)=\mathrm{MSe}$

Where,

MSg and MSe are the mean sum of squares for the genotypes and error in the analysis of variance, respectively.

$r$ is the number of replications.

Then, the phenotypic variance was estimated as the sum of the genotypic and environmental variances:

Phenotypic variance $\left(\sigma^{2} \mathrm{ph}\right)=\sigma^{2} \mathrm{~g}+\sigma^{2} \mathrm{e}$

\section{Genotypic and phenotypic coefficient of variations}

The genotypic and phenotypic coefficients of variability were estimated according to the formulae of Singh and Chaudhary, (1977) as follows

Genotypic Coefficient of Variation $(\mathrm{GCV})=(\sigma \mathrm{g} / \mathrm{grand}$ mean)*100

Phenotypic Coefficient of Variation $(\mathrm{PCV})=(\sigma \mathrm{ph} / \mathrm{grand}$ mean)*100

Where: $-\sigma g$ and $\sigma p h$ are genotypic and phenotypic standard deviations, respectively.

\section{Heritability analysis}

Broad sense heritability values were estimated based on the formula of Falconer et al., 1996 as follows:

Heritability in broad sense $\left(\mathrm{H}^{2}\right)=\left(\sigma^{2} \mathrm{~g} / \sigma^{2} \mathrm{ph}\right) * 100$

Then, the genetic advance for selection intensity $(\mathrm{k})$ at $5 \%$ was estimated by the following formula (Allard, 1960):

$\mathrm{EGA}=\mathrm{k}^{*} \sigma \mathrm{ph} * \mathrm{H}^{2}$
Where,

EGA represents the expected genetic advance under selection;

$\sigma p h$ is the phenotypic standard deviation;

$\mathrm{H}^{2}$ is heritability in broad sense and $\mathrm{k}$ is selection intensity.

The genetic advance as percent of population mean was also estimated following the procedure of Johnson et al., (1955).

\section{Genetic divergence analysis}

Genetic divergence analysis was computed based on multivariate analysis using Mahalanobis's $\mathrm{D}^{2}$ statistic (Mahalanobis, 1936) by using SAS Computer Software Program.

As Sneath and Sokal (1973) indicated, Euclidean distance (ED) were computed from the 10 morphphysiological traits of 14 cotton genotypes after standardization (subtracting the mean value and dividing it by the standard deviation) as follows:

$$
\mathbf{E D}_{j k}=\sqrt{\sum_{i=1}^{n}\left(x_{i j}-x_{i k}\right)^{2}}
$$

Where,

$\mathrm{EDjk}=$ distance between cultivars $\mathrm{j}$ and $\mathrm{k}$; $\mathrm{xij}$ and $\mathrm{xik}=$ morph-physiological traits values of the $i^{\text {th }}$ character for genotype $\mathrm{j}$ and $\mathrm{k}$, respectively; and $\mathrm{n}=$ number of morph-physiological traits used to calculate the distance.

The distance matrix from morph-physiological traits was used to construct dendrograms based on the Un-weighted Pair-group Method with Arithmetic means (UPGMA). The results of cluster analysis were presented in the form of dendrogram. In addition, mean ED was calculated for each genotype by averaging of a particular genotype to the other 14 varieties. The calculated averages distance (ED) was used to estimate which genotype is closest or distant to the others based on their mean performance.

\section{Results and Discussions}

The mean square from analysis of variance showed highly significant $(\mathrm{P}<0.01)$ differences among cotton genotypes were observed for days to $50 \%$ flowering, 
days to $65 \%$ boll opening, plant height, number of monopodial branches per plant, number of sympodial or fruiting branches per plant, number of bolls per plant, for average boll weight, seed cotton yield, lint yield, and lint percentage or ginning outturn (GOT).

\section{Range and mean values of cotton genotypes}

Range and mean values for tested cotton genotypes are presented in Table3. Traits like days to $50 \%$ flowering ranged from 82.67 to 93.00 days while days to $65 \%$ boll opening ranged from 145 to 167 days. Shorter number of days to flower setting and boll opening indicated earliness of certain tested lines. The early flowering entry was the check Deltapinee-90 with 82.7 days from emergence followed by WARC-4 with 88.3 days. The late flowering lines were WARC-5 and WARC-1 with 93.0 and 92.7 days, respectively. The remaining entries were intermediate and ranged from 90.0 to 91.3 days. Deltapine-90 was also the early boll opener at 145 days and WARC-12 was the latest at 165.7 days after emergence (Table3). Ali and Khan (2003) have taken to flowering is considered as an important determinant of earliness. (Iqbal and Jabbar, 2011) also found positive linkage between first flower formation and earliness. Hence, delay in flowering is a sign of late maturity which may be okay in non-moisture stress areas. Plant height ranged from $99.60 \mathrm{~cm}$ to $186.53 \mathrm{~cm}$ with the mean value of 133.48 and indicated a wide variation among genotypes. Variations of genotypes for other traits are demonstrated in Table 3.

Seed cotton yield (SCY) ranged from 1601.20 to 2724.70 $\mathrm{kg} / \mathrm{ha}$ with a mean value of $2207.20 \mathrm{~kg} / \mathrm{ha}$. The top yielders, as shown in Table 5, included WARC-4, WARC-8, WARC-3, WARC-9, WARC-11 and the check Deltapine-90 with 2724.9, 2583.7, 2564.9, 2433.1, 2353.1 and $2413.3 \mathrm{~kg} / \mathrm{ha}$, respectively. These entries with the exception of WARC-3 have satisfactory levels of lint percentages and could serve as good source for cotton variety improvement. Lint is a major and most important component of cotton production, and a vital raw material for the textile industry.

Boll number per plant $(\mathrm{BN})$ and boll weight $(\mathrm{BWt})$ are important yield components that contributed to increased seed cotton (Table 5). Entries with higher boll number than the trial mean $(3.62 \mathrm{~g})$ included WARC-2, WARC5, WARC-6, WARC-10 and the two checks Deltapine-90 and Stam-59A. These test entries also had ball weights larger than the mean with the exception of WARC-6 and Stam-59A (Table 5). Larger number of bolls indicated the capacity of certain entries to retain more productive bolls under stress or otherwise.

\section{Estimation of broad-sense heritability}

GCV alone is not helpful for effective selection, but together with heritability estimates could determine the extent of selection response (Mahaingam et al., 2013). Estimate of broad sense heritability for 10 traits of Cotton genotypes were ranged from $63 \%$ to $92 \%$ for days to $65 \%$ boll opening and days to $50 \%$ flowering respectively (Table 5). In this study heritability's of genotypes were categorized as high, moderately high and low heritability ranges. High heritability were noted for plant height, number of monopodial branch per plant, number sympodial branches per plant, boll number per plant and ginning out turn indicating these traits affected less than others by the environmental factor (Amir et al., 2012 and Ali et al., 2011) have similar findings. Moderately high heritability was observed for days to $65 \%$ boll opening, boll weight, seed cotton yield and lint yield. And heritability estimates for number of monopodial branches per plant (6.67\%) and plant height (20.60\%) were low. Killi et al., (2005) also agree with this findings.

\section{Euclidean Distance of Gossypium hirustum Genotypes}

Estimates of genetic distance were ranged from 2.3 to 97.7 with a mean of 14.17. The highest distance was observed for WARC-4 and Stam-59A (97.7) followed by Deltapine 90 and Stam-59A (97.1) and the lowest distance was noted for WARC-6 and WARC-9, (2.3), followed by WARC-5 and WARC-11 (3.3) (Table 6).

Cluster analysis based on the Euclidean distance (ED) matrix is presented in Figure 1. From the Figure two groups were formed each with a sub-group and the third cluster is solitary and comprised a single genotype which is Stam-59A (7.15\%). The remaining 13 cotton varieties $(92.85 \%)$ including one standard check variety Deltapine 90 formed two larger groups. The first large group consisted WARC-5, WARC-11, WARC-12 and Deltapine 90. The second larger group had two subgroups; the first sub-group consisted of WARC-1, WARC-6, WARC-10 and WARC-9, while the second sub-group comprised WARC-7, WARC-2, WARC-3, WARC-4 and WARC-8.

The solitary genotype, Stam-59A, is characterized by tall stem and long monopodial branches; under high rainfall and windy conditions, it has a tendency to lodge. The 
presence of genetic diversity among the tested genotypes is appreciable, and crossing of lines from the different clusters could produce heterotic $F_{1}$ 's and a wide range of variability in subsequent segregating populations from which to select and advance promising types. According to Ghaderi et al., (1984) increasing parental distance implies a great number of contrasting alleles at the desired loci, and then to the extent that these loci recombine in the $F_{2}$ and $F_{3}$ generation following a cross of distantly related parents and the greater will be the opportunities for the effective selection for yield factors.

Table.1 Fourteen Cotton seed materials used in the study

\begin{tabular}{llll}
\hline $\begin{array}{l}\text { Entry } \\
\text { number }\end{array}$ & Codes & Pedigree/Designation & $\begin{array}{l}\text { Selection } \\
\text { number }\end{array}$ \\
\hline 1 & WARC-1 & HTO\#052 x Deltapine 90 & $21-7$ \\
2 & WARC-2 & Cucurova1518 x LG-450 & $35-4$ \\
3 & WARC-3 & Deltapine 90 x Cucurova1518 & $37-7$ \\
4 & WARC-4 & Deltapine 90 x Stam-59A & $38-8$ \\
5 & WARC-5 & Del Cero x GL-7 & $8-2$ \\
6 & WARC-6 & ISA 205H x Stam-59A & $11-4$ \\
7 & WARC-7 & ISA 205H x Beyazealtin/5 & $16-2$ \\
8 & WARC-8 & HS-46 x Stoneville 453 & $19-2$ \\
9 & WARC-9 & HS-46 x Stoneville 453 & $19-8$ \\
10 & WARC-10 & Stam-59 A x Cucurova 1518 & $30-2$ \\
11 & WARC-11 & Stam-59 A x Cucurova 1518 & $30-6$ \\
12 & WARC-12 & Stam-59A x Europa-5 & - \\
13 & (Check-1) & Deltapine 90 (na $\left.{ }^{+}\right)$ & - \\
14 & (Check-2) & Stam-59A $\left(\right.$ na $\left.^{+}\right)$ & - \\
\hline na ${ }^{+}=$Pedigree not available & &
\end{tabular}

Table.2 Analysis of variance (mean square) for 10 traits of 14 experimental cotton varieties

\begin{tabular}{llll}
\hline Traits & Replication & Genotypes & Error \\
\hline D50\%F & $1.50 \mathrm{~ns}$ & $18.35^{* *}$ & 1.60 \\
$\mathrm{D} 65 \% \mathrm{BO}$ & $141.07^{*}$ & $111.53^{* *}$ & 37.56 \\
$\mathrm{PHt}$ & $2483.62^{* *}$ & $1545.68^{* *}$ & 291.53 \\
$\mathrm{NMB}$ & $0.74 \mathrm{~ns}$ & $3.91^{* *}$ & 0.45 \\
$\mathrm{NSyB}$ & $0.57 \mathrm{~ns}$ & $2.65^{* *}$ & 0.32 \\
$\mathrm{NB}$ & $1.87 \mathrm{~ns}$ & $6.48^{* *}$ & 0.81 \\
$\mathrm{BWt}$ & $0.21 \mathrm{~ns}$ & $0.22^{* *}$ & 0.08 \\
$\mathrm{SCY}$ & $235570.91 \mathrm{~ns}$ & $332418.31^{* *}$ & 96973.04 \\
$\mathrm{LY}$ & $45356.15 \mathrm{~ns}$ & $56175.97 * *$ & 17464.58 \\
$\mathrm{GOT}$ & $6.60 * *$ & $7.93^{* *}$ & 0.89 \\
\hline
\end{tabular}

*, ** Indicate significance and highly significance difference at the 0.05 and 0.01 levels, respectively; ns=non-significant; $\mathrm{D} 50 \% \mathrm{~F}=$ Days to $50 \%$ flowering, $\mathrm{D} 65 \% \mathrm{BO}=$ Days to $65 \%$ boll opening, $\mathrm{PHt}=\mathrm{Plant}$ height, $\mathrm{NMB}=\mathrm{Number}$ of monopodial branches/plant, $\mathrm{NSyB}=$ Number of sympodial branches/plant, $\mathrm{NB}=$ Number of bolls per plant, $\mathrm{BWt}=\mathrm{Boll}$ weight in grams, $\mathrm{SCY}=$ Seed cotton yield in $\mathrm{kg}$ per ha, $\mathrm{LY}=$ Lint yield in $\mathrm{kg}$ per ha and GOT=Ginning out turn 
Table.3 Minimum and maximum values with the corresponding genotypes for ten traits of cotton genotypes

\begin{tabular}{llllllll}
\hline Traits & $\begin{array}{l}\text { Min. } \\
\text { Value }\end{array}$ & $\begin{array}{l}\text { Genotypes with } \\
\text { Min. value }\end{array}$ & $\begin{array}{l}\text { Max. } \\
\text { value }\end{array}$ & $\begin{array}{l}\text { Genotype with } \\
\text { Max. value }\end{array}$ & Mean & SE & CV (\%) \\
\hline D50\%F & 82.67 & Deltapine-90 & 93.00 & WARC-5 & 90.29 & 0.73 & 1.42 \\
D65\%BO & 145.00 & Deltapine-90 & 167.00 & Stam-59A & 159.29 & 3.51 & 3.72 \\
PHt & 99.60 & Deltapine-90 & 186.53 & Stam-59A & 133.48 & 9.86 & 12.79 \\
NMB & 6.21 & WARC-2 & 10.22 & WARC-3 & 8.76 & 0.39 & 7.66 \\
NSyB & 7.46 & WARC-11 & 10.98 & WARC-6 & 8.89 & 0.33 & 6.33 \\
NB & 20.00 & WARC-7 & 24.69 & Deltapine-90 & 22.17 & 0.52 & 4.05 \\
BWt & 2.95 & Stam-59A & 3.95 & WARC-10 & 3.62 & 0.16 & 7.82 \\
SCY & 1601.00 & WARC-1 & 2725.00 & WARC-4 & 2207.20 & 180 & 14.11 \\
LY & 645.00 & WARC-1 & 1140.00 & WARC-4 & 914.45 & 76.3 & 14.45 \\
GOT & 37.60 & WARC-3 & 43.62 & WARC-10 & 41.46 & 0.54 & 2.27
\end{tabular}

D50\% $\mathrm{F}=$ Days to $50 \%$ flowering, D65\%BO=Days to 65\% boll opening, PHt= Plant height, NMB=Number of monopodial branches/plant, $\mathrm{NSyB}=$ Number of sympodial branches/plant, $\mathrm{NB}=$ Number of bolls per plant, $\mathrm{BWt}=\mathrm{Boll}$ weight in grams, $\mathrm{SCY}=$ Seed cotton yield in $\mathrm{kg}$ per ha, LY= Lint yield in $\mathrm{kg}$ per ha and GOT=Ginning out turn

Table.4 Mean values of 10 traits of 14 cotton genotypes

\begin{tabular}{|c|c|c|c|c|c|c|c|c|c|c|}
\hline \multirow{2}{*}{$\begin{array}{l}\text { Cotton } \\
\text { Genotypes }\end{array}$} & \multicolumn{10}{|c|}{ Mean values of tested Cotton genotypes } \\
\hline & $\mathrm{D} 50 \% \mathrm{~F}$ & $\mathrm{D} 65 \% \mathrm{BO}$ & PHt & NMB & NSyB & NBP & $\mathrm{BWt}$ & SCY & LY & $\mathrm{L} \%$ \\
\hline WARC-1 & $92.7 \mathrm{ba}$ & 158.0bdac & $103.6 \mathrm{~d}$ & 7.1ef & $8.8 \mathrm{ced}$ & 21.6dce & $3.75 \mathrm{dac}$ & $1601.2 \mathrm{e}$ & $44.6 \mathrm{~d}$ & $40.26 \mathrm{ed}$ \\
\hline WARC-2 & $90.7 b c$ & 161.3bdac & $120.7 \mathrm{~cd}$ & $6.2 \mathrm{fa}$ & $9.8 \mathrm{~b}$ & $24.2 \mathrm{a}$ & $3.52 \mathrm{dac}$ & $2202.2 b c$ & $917.4 \mathrm{ba}$ & $41.66 \mathrm{bdc}$ \\
\hline WARC-3 & $90.7 \mathrm{bc}$ & $167.0 \mathrm{a}$ & $142.3 \mathrm{cb}$ & $10.2 \mathrm{a}$ & 8.0fg & $21.2 \mathrm{dce}$ & $3.93 \mathrm{ba}$ & $2564.9 \mathrm{ba}$ & $965.4 \mathrm{ba}$ & $37.64 \mathrm{f}$ \\
\hline WARC-4 & $3.3 \mathrm{~d}$ & 156.7 & 116. & $7.8 \mathrm{ecd}$ & & & $84 \mathrm{bac}$ & 4.9a & $.5 \mathrm{a}$ & $2 \mathrm{bdc}$ \\
\hline WARC & $93.0 \mathrm{a}$ & $152.3 \mathrm{de}$ & $119.1 \mathrm{~cd}$ & 7.7ed & 8.8ebd & $22.2 \mathrm{bc}$ & $3.59 \mathrm{dac}$ & 2017.5edc & $856.9 \mathrm{bcd}$ & $42.47 \mathrm{bac}$ \\
\hline WAF & $.0 \mathrm{dc}$ & 159.3 & $44.3 \mathrm{cb}$ & $9.6 \mathrm{ba}$ & $11 .($ & 24. & 3.33 & 166 & 686 & \\
\hline & $.0 \mathrm{bac}$ & 160 & & $8.9 \mathrm{bc}$ & 8.4egd & & & & & \\
\hline & s & 154 & $\mathrm{cb}$ & $8.6 \mathrm{bcd}$ & $7.7 \mathrm{~g}$ & & & 258 & & \\
\hline & & & & 9. & & & & & & \\
\hline & & & & & & & & & & \\
\hline WARC-11 & & 163.0bac & & $8.9 \mathrm{bc}$ & $7.5 \mathrm{~g}$ & $20.4 \mathrm{e}$ & & & $1004.1 \mathrm{ba}$ & 42.67bac \\
\hline WARC-12 & $90.3 \mathrm{dc}$ & $165.7 \mathrm{dcdc}$ & $152.1 \mathrm{~b}$ & $9.5 \mathrm{ba}$ & $8.2 \mathrm{feg}$ & $22.0 \mathrm{dc}$ & 3.74dac & $2184.7 \mathrm{bdc}$ & $869.5 b c$ & $39.80 \mathrm{e}$ \\
\hline Deltapine-90 & $82.7 \mathrm{e}$ & $145.0 \mathrm{e}$ & $99.6 \mathrm{~d}$ & $9.7 \mathrm{ba}$ & $9.7 \mathrm{cb}$ & $24.7 \mathrm{a}$ & $3.47 \mathrm{bdc}$ & $2413.3 \mathrm{bac}$ & $976.2 \mathrm{ba}$ & 40.45ed \\
\hline Stam-59A & $91.7 \mathrm{bac}$ & $167.3 \mathrm{a}$ & $186.5 \mathrm{a}$ & $9.4 \mathrm{ba}$ & $9.3 \mathrm{cbd}$ & $23.7 \mathrm{ba}$ & $2.95 \mathrm{e}$ & $2035.3 \mathrm{edc}$ & $850.7 \mathrm{bcd}$ & $41.80 \mathrm{bdc}$ \\
\hline Trial mean & 90.3 & 159.3 & 133.5 & 8.76 & 8.9 & 22.16 & 3.62 & 2207.20 & 914.44 & 41.46 \\
\hline $\mathrm{CV}(\%)$ & 1.42 & 3.85 & 12.79 & 7.66 & 6.33 & 4.05 & 7.82 & 14.11 & 14.45 & 2.27 \\
\hline $\operatorname{LSD}\left({ }_{0.05}\right)$ & 2.16 & 10.29 & 28.66 & 1.13 & 0.95 & 1.51 & 0.48 & 522.60 & 221.8 & 14.45 \\
\hline
\end{tabular}

* Within columns, values having a letter in common are not significantly different at the $5 \%$ significance level.

$\mathrm{D} 50 \% \mathrm{~F}=$ Days to $50 \%$ flowering; $\mathrm{D} 65 \% \mathrm{BO}=$ Days to $65 \%$ boll opening; $\mathrm{PHt}=\mathrm{Plant}$ height; $\mathrm{NMB}=\mathrm{Number}$ of monopodial branches per plant; $\mathrm{NSyB}=$ Number of sympodial branches per plant; $\mathrm{NB}=$ Number of bolls per plant; $\mathrm{BWt}=\mathrm{Boll}$ weight in grams; SCY=Seed cotton yield in kg per ha; LY=Lint yield in kg per ha; L\%= GOT (Ginning out turn). 
Table.5 Genotypic, phenotypic and environmental variance and coefficient of variation, broad sense heritability and genetic advance. For 10 traits of Cottons genotypes in Kamashi district

\begin{tabular}{llllllllllll}
\hline Traits & Range & Mean & SE & PV & GV & EV & PCV\% & GCV\% & H $^{2}$ & GA & GAM\% \\
\hline D50\%F & $82.66-93.00$ & 90.28 & 0.73 & 19.40 & 17.82 & 1.60 & 4.88 & 4.68 & 0.92 & 8.34 & 9.24 \\
D65\%B & $145.00-167.33$ & 159.80 & 3.51 & 99.30 & 62.40 & 36.90 & 6.24 & 4.94 & 0.63 & 12.92 & 8.08 \\
PHt & $99.60-186.53$ & 133.48 & 9.86 & 1740 & 1448.50 & 291.53 & 31.25 & 28.51 & 0.83 & 71.64 & 53.67 \\
NMB & $6.21-10.22$ & 8.76 & 0.39 & 4.20 & 3.76 & 0.45 & 23.42 & 22.14 & 0.89 & 3.78 & 43.16 \\
NSyB & $7.46-10.97$ & 8.89 & 0.33 & 2.90 & 2.54 & 0.32 & 19.03 & 17.94 & 0.89 & 3.10 & 34.88 \\
NB & $20.11-24.68$ & 22.16 & 0.52 & 7.00 & 6.22 & 0.81 & 11.96 & 11.25 & 0.88 & 4.84 & 21.84 \\
BWt & $2.95-3.93$ & 3.62 & 0.16 & 0.30 & 0.19 & 0.08 & 14.44 & 12.15 & 0.71 & 0.76 & 21.07 \\
SCY & $1601.20-2724.76$ & 2207.26 & 179.79 & 397067.0 & 300094.0 & 96973.0 & 28.55 & 24.82 & 0.76 & 883.98 & 40.05 \\
LY & $644.60-1139.50$ & 914.44 & 76.30 & 67819.03 & 50354.45 & $17464.5 £$ & 28.48 & 24.54 & 0.74 & 365.33 & 39.95 \\
GOT & $37.64-43.43$ & 41.45 & 0.54 & 8.53 & 7.64 & 0.89 & 7.04 & 6.67 & 0.90 & 4.10 & 9.88
\end{tabular}

D50\% F=Days to $50 \%$ flowering; $\mathrm{D} 65 \% \mathrm{BO}=$ Days to $65 \%$ boll opening; $\mathrm{PHt}=\mathrm{Plant}$ height; $\mathrm{NMB}=$ Number of monopodial branches per plant; $\mathrm{NSyB}=$ Number of sympodial branches per plant; $\mathrm{NB}=$ Number of bolls per plant; $\mathrm{BWt}=$ Boll weight in grams; LY=Lint yield in kg per ha; $\mathrm{L} \%=$ Lint percentage or GOT (Ginning out turn); SCY=Seed cotton yield in kg per ha.

Figure.1 Dendrogram generated based on UPGMA clustering method depicting genetic relationships among 14 cotton varieties based on 10 morphological traits

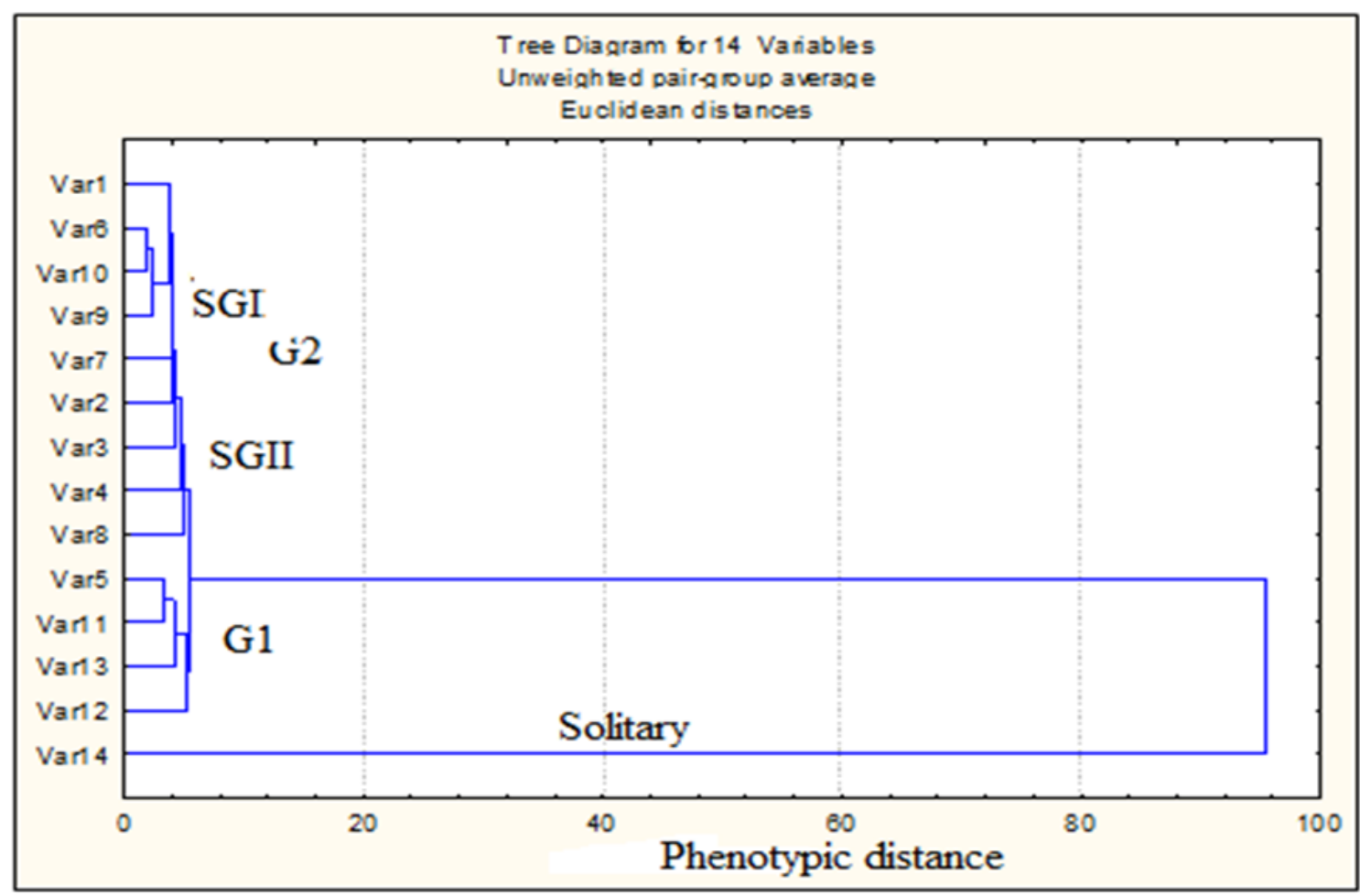

Note: Var1=WARC-1, Var2=WARC-2, Var3=WARC-3, Var4=WARC-4, Var5=WARC-5, Var6=WARC-6, Var7=WRC-7, Var8=WARC-8, Var9=WARC-9, Var10=WARC-10, Var11=WARC-11, Var12=WARC-12, Var13=Daltapine-90, Var14=Stam-59A 
Table.6 Euclidean distance of 14 cotton genotypes measured from 14 phenological traits

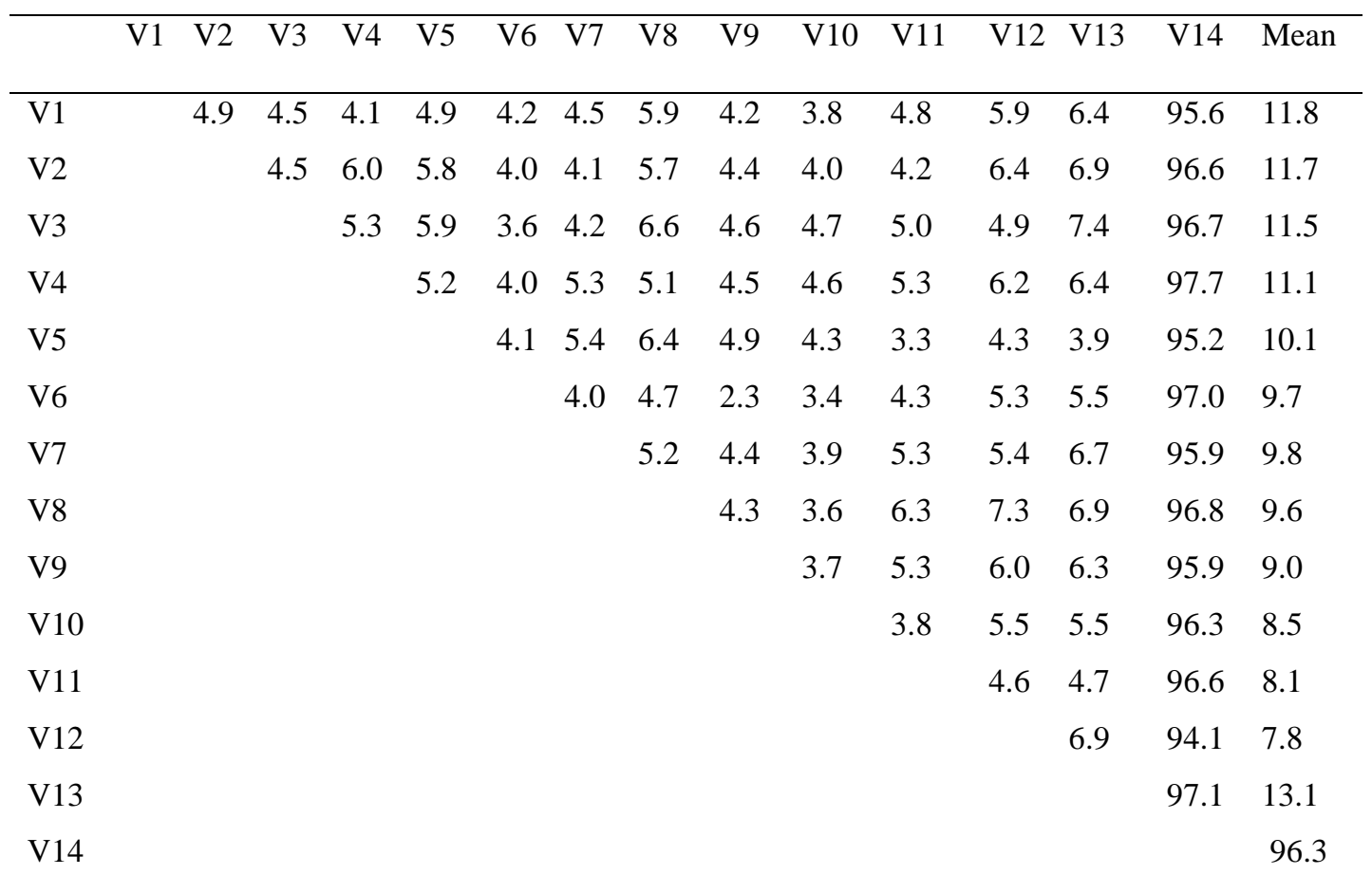

Note: -V1=WARC-1, V2=WARC-2, V3=WARC-3, V4=WARC-4, V5=WARC-5, V6=WARC-6, V7=WARC-7, V8=WARC-8, V9=WARC-9, V10=WARC-10, V11=WARC-11, V12=WARC-12, V13=Deltapine90, V14=Stam-59A

The magnitude and structure of genetic variation detected from the diversity analysis could be used in breeding programs (Koutis et al., 2012). Generally, the more distant the parents are for crossing, the better the chance to obtain heterotic hybrids, and the broader the genetic base of the varieties to be developed.

\section{Conclusions}

The analysis of variance showed significant differences among the tested genotypes for all characters considered in the study; this indicated the existence of variability among the tested genotypes. Phenotypic variances and phenotypic coefficients of variation were higher than their respective genotypic variances and genotypic coefficients of variation for all the traits considered in the study. This indicated the presence of environmental influence to some degree in the phenotypic expression of the traits. Higher phenotypic coefficients of variation were recorded for plant height, number of monopodial branches per plant, seed cotton yield and lint yield traits.

Heritability estimates for genotypes were found to be moderately high for days to $65 \%$ boll opening, boll weight, seed cotton yield and lint yield. And genotypes which have high range of heritability were noted for plant height, number of monopodial branches per plant, number of sympodial branches per plant, number of bolls per plant and lint percentage, indicating that these traits are less affected by environmental conditions. Plant height, number of monopodial branches per plant and number of bolls per plant showed high heritability $(83 \%$, $89 \%$ and $89 \%$, respectively) with high genetic advances in percent of mean $(53.67,43.16$, and 54.45, respectively). The integration of high heritability with high response to selection will provide high reliability in selection of those specific traits

Euclidean genetic distance of the genotypes was estimated based on means of genotypes. The distance analysis classified 14 cotton genotypes into two classes. This indicates the presence of diversity among the tested genotypes. Clusters I (7.15\%) was the least cluster containing one genotype and Cluster II contained the largest groups of genotypes (92.85\%). Thus, crossing of genotypes from these two clusters may produce heterotic $\mathrm{F}_{1}$ 's and wide range of variability in subsequent segregating $\left(\mathrm{F}_{2}\right)$ populations. 
The top four genotypes that performed better than the released check varieties for seed cotton yield were WARC-4, WARC-8, WARC-3, and WARC-9, with seed cotton yields of $2724.9,2583.7,2564.9$, and $2433.1 \mathrm{~kg}$ per hectare, respectively. Seed cotton yields of the standard checks were $2035.3 \mathrm{~kg}$ per hectare for Deltapine 90 and $2413 \mathrm{~kg}$ per hectare for Stam-59A.

In this study, looking at the mean seed cotton yield, the lint percentage and mean lint yield, six top performing entries deserve variety verification evaluations in BenshangulGumuze and other similar rain-fed areas. Finally adaptation, demonstration and promotion on farmers' fields should follow if any or all of these lines meet the national variety release requirements during the verification process.

\section{Conflict of interest}

There are no conflicts of competition of interests in this paper.

\section{Acknowledgments}

My special appreciation and deepest thanks go to Dr. Bedada Girma and to Dr. GudetaNepir for their encouragement, suggestions, guidance and overall assistance during my study period. And I want to express my deepest gratitude and appreciation to EIAR for sponsoring my study through provision of research grant. My thanks also go to Werer Agricultural Research Center for providing me with seeds of cotton varieties for my research work.

\section{References}

Allard, R.W. 1960. Principles of Plant Breeding. John Wiley and Sons. Inc. New York.

Ali, M.A., and I.A. Khan. 2003. Assessment of genetic variation and inheritance mode in some metric traits of cotton (Gossypium hirsutum L.) J. Agri. Social Sci. 3:112-116.

Anonymous. 2008. Breeding Better Cotton [online] available from [http:// www.ars.usda.gov/is/AR/archive/feb08/fabric

Amir, S., J. Farooq, A. Bibi, S.H. Khan, and M.H. Saleem. 2012. Genetic studies of earliness in Gossypium hirsutum L. IJAVM S 6 (3):189-207.

Assosa Agricultural Research Center (AsARC), 2011. Farming system survey document.
Berger, H. 1969 (ed.) The world major fiber crops, their cultivation and manuring. Centre d'étude de l'azote 6. Zurich, Switzerland.

Burton, G.W., and, E.H. Devane. 1953. Estimating heritability in tall Fescue (Festuca arundinacea) from replicated clonal materials. Agron. J. 45:487488.

Campbell, B.T., S. Saha, R. Percy, J. Frelichowski, J.N. Jenkins, W. Park, C.D. Mayee, V. Gotmare, D. Dessauw, M. Gband, X. Du, Y. Jia, G. Constable, S. Dillon, I.Y. Abdurakhmonov, I.Y., A. Abdukarimov, S.M. Rizaeva, A.A. Abdullaev, P.A.V. Barrose, J.G. Padua, L.V. Hoffman, and L. Podolnaya. 2010. Status of Global Cotton Germplasm Resources. Crop Sci. 50 (4):1161-1179.

Chen, Z.J., B.E. Scheffler, E. Dennis, B.A. Triplett, T. Zhang, W. Guo, X. Chen, M.D. Stelly, P.D. Rabinowicz, C.D. Town, T. Arioli, C. Brubaker, R.G. Cantrell, J.M. Lacape, M. Ulloa, P. Chee, A.R. Gingle, C.H. Haigler, R. Percy, S. Saha, T. Wilkins, R.J. Wright, A. Van Deynze, Y. Zhu, S. Yu, I Abdurakhmonov, I. Katageri, P.A. Kumar, Z.Y. Mehboob-Ur-Rahman, J.Z. Yu, R.J. Kohel, J.F. Wendel, and A.H. Paterson. 2007. Towards Sequencing Cotton (Gossypium) Genomes. Plant Physiology, Vol. 145, No. 4, (Dec 2007). p. 13031310, ISSN 1532-2548.

European Commission, the Textile and Clothing Sector, and EU Trade Policy, February. 2011. http://trade.ec.europa.eu/doclib/docs/2011/october/t radoc_148259.pdf

Falconer, D.S. and Trudy F.C. Mackay. 1996. Introduction to Quantitative Genetics. 4th Ed., Longman Group Limited, Malaysia. 464p.

Ghaderi, A., M.W. Adams, and A.M. Nassib. 1984. Relationship between genetic distance and heterosis for yield and morphological traits in dry edible bean and broad bean. Crop Sci., 24:37-24.

Gomez, A.K., and A.A. Gomez. 1984. Statistical procedures for agricultural research, 2nd Ed. New York, NY: John Wiley and Sons.

Killi, F., L. Efe and S. Mustafayev. 2005. Genetic and environmental variability in yield, yield components and lint quality traits of cotton. Int. J. Agri. Biol. 7 (6):1007-1010.

Koutis, K., A.G. Mavromatis, D. Baxevanos and M. Koutsika. 2012. Multi environmental evaluation of wheat landraces by GGE biplot analysis for organic breeding. Agri. Sci., 3: 66-74.

Lee, S., J.C. Hong, W.B. Jeon, Y.S. Chung, S. Sung, D. Choi, Y.H. Joung and B.J. Oh. 2009. The Salicylic Acid-Induced Protection of Non-Climacteric Unripe 
Pepper Fruit against Colletotrichum gloeosporioidesis Similar to the Resistance of Ripe Fruit. Plant Cell Report, Vol.28, No.10, (August 2009). p. 1573-1580.

Mahalanobis, P.C. 1936. The generalized distance in statistics. Pro. Nat. Inst. Sci. India, 2:49-55.

Mahalingam, A., R. Saraswathi, J. Ramalingam and T. Jayaraj. 2013. Genetics of floral traits in cytoplasmic male sterile (CMS) and restorer lines of hybrid rice (Oryza sativa L.). Pak. J. Bot. 45 (6):1897-1904.

Preetha, S. and T.S. Raveendran. 2007. Genetic variability and association studies in three different morphological groups of cotton (Gossypium hirsutum L.) Asian J. Plant Sci., 6 (1):122-128.

Robertson, G.E., 1959. The sampling variance of the genetic correlation coefficient. Biometrics. 15:469485 .

SAS, (Statistical Analysis System, 2002.) Version 9.0. SAS Institute Inc., Cary, NC, USA.

Seelanan, T. and A.J.F. Schnable. 1997. Congruence and consensus in the cotton tribe (Malvaceae). Systematic Botany 22:259-290.

Singh,.R.K. and B. D. Chaudhary. 1977. Biometrical methods in quantitative genetic analysis. Kalyani publishers, New Delhi, Ludhiana, India. 318p.
Sneath, P.H. and R.R. Sokal. 1973. Numerical Taxonomy. Freeman and Company, San Francisco, USA.

SOFERCO. 2016. National Cotton Development Strategy for Ethiopia (2015-2030).

Spectrum Commodities, Cotton: World Supply and Demand, accessed 30 June 2012. http://www.spectrumcommodities.com/education/co mmodity/statistics/cottontable.html

Tsedeke Abate, 2007. Focusing agricultural research to address development needs: directions for agricultural research, EIAR, p. 14-15. United States Department of Agriculture, (2016), Cotton: World Markets and Trade

Valderrama, C.A., undated. 2007. Profile of the International Cotton Advisory Committee. [Online] Available

from: http://www.newrules.org/docs/ffdconsultdocs/valder rama.Pdf.

Wendel J.F., and C.E. Grover. 2015. Taxonomy and Evolution of the Cotton Genus, Gossypium. Cotton 57: 25-44.

Zhang H.B., Y. Li, B. Wang, and P.W. Chee. 2008. Recent advances in cotton genomics. Intl. J. Plant Genomics 742304: 1-20.

\section{How to cite this article:}

Kedir Wulchafo Hussen. 2019. Genetic Distance and Variation among Cotton (Gossypium hirsutum L) Genotypes for Yield Traits in Kamashi District of Benishangul-Gumuz Regional State, Ethiopia. Int.J.Curr.Res.Aca.Rev. 7(4), 91-100. doi: https://doi.org/10.20546/ijcrar.2019.704.010 